\title{
The Thinking Way of Confucianism and the Rule of Law
}

\author{
Guoji Qin \\ Department of Politics and Law, Shenyang Institute of Engineering \\ No.18, 3rd Zheng-yi Road, Dao-yi Economic Zone, Shenyang 110136, China \\ Tel: 86-24-31975679Ｅ-mail: qingj67@hotmail.com
}

\begin{abstract}
Confucianism as the old ideology had been criticized for a long time from the official point of view in China; however, its core value is still influencing Chinese society. On the way towards road of the rule of law, Confucianism is considered playing the negative role. It is necessary to study the framework of Confucianism systematically so as to understand why the rule of law shows difference in between China and western world, and why Chinese would rather resolve disputes in Confucianism way than the rule of law. I will discuss the thinking way of Confucianism, analyze its core value and the relation between Confucianism and the rule of law, through which get to the conclusion that Confucianism value has the inclination to avoid the law.
\end{abstract}

Keywords: Confucianism, The Rule of man, The Rule of Law

\section{Introduction}

It seems strange that Confucianism is still influential in China after "May Fourth Movement" (1919), especially after "Cultural Revolution Movement" (1966-1976). Youngsters today know little about Confucius or Mencius, let alone Confucianism. However, the Confucianism textbook "Three Characters Premier" and "Qian Zi Wen" have been taught by parents even during the toughest period. The classical novels written with the Confucian thoughts are very popular in China.

Richard Nixon, the ex-president of U.S.A wrote in his work "Leaders" that Zhou Enlai, the ex-premier of China, answered the question from a foreigner reporter that: "as a member of communist party, are you more a Chinese or more a communist?" Zhou replied: "I am more a Chinese." He (Zhou Enlai) said that Chinese welcome any Americans to come to China, but it should be reciprocal between each other. There is a saying in China that "it is impolite not to reciprocate." He stressed that it is said by Confucius who was not a Marxist. It was unusual when it was spoken out by Zhou Enlai, one of the main leaders in Communist Party, at the time that stressed political stand. However, there is no question that the influence of Confucianism exists strongly in China, and Zhou Enlai was regarded as the perfect practitioner of Confucianism with his perfect virtue.

Confucianism as the old ideology had been criticized for a long time from the official point of view in the past. However, Confucianism didn't lose its core value actually. Perfect virtue, the Middle Way, and the authority admiration are still its salient features. The authority with the perfect virtue doing in the middle way is the perfect ideal to Chinese people. Zhou Enlai is just that type of man who is regarded as the person with all these characteristics.

There is confusion when the rule of law tries to come into China and be the fundamental pattern to rule the country. Whether the tradition rooted in Chinese be the obstacle to the rule of law, or the rule of law can replace the traditional value successfully with its distinguishing values?

Confucianism was mainly criticized because it stresses on the submission and ignores the human rights; whereas, the rule of law stresses human rights as the core value. It seems there is no space for them to sit together and have a dialogue. Why is that? Why does Confucianism ignore human rights? Why cannot Confucianism and the rule of law find a connecting point in between each other? And what role the perfect virtue and the Middle Way of Confucianism play to the rule of law?

It is necessary to analyze the fundamental value of Confucianism systematically so as to understand why the rule of law shows difference between China and western world, and why Chinese would rather resolve disputes in Confucianism way than the rule of law.

\section{The Fundamental Value of Confucianism}

There are three basic elements in Confucianism: "Ren", "Li" and "Dao", which show the fundamental value of Confucianism. It is very necessary to analyze these basic elements and find the relationship among them, so as to 
picture the thinking way of Confucianism and its difference from the rule of law.

\section{1 "Ren" (Benevolence)}

There are two answers by Confucius about "Ren" in Analects. One is: "to love all man." (James Legge, 1966, pp. 171) and the other one is: "To subdue oneself and return to propriety (Li)" (James Legge, 1966, pp. 155). Chinese structure of "Ren" is comprised of two parts, the left part means the "person" and the right part means the number "two". It hints that Ren is about the relationship between people, and the relationship of Ren will be established when the people consider for others. For instance, Confucius said: "Now the man of perfect virtue ("Ren"), wishing to be established himself, seeks also to establish others; wishing to be enlarged himself, he seeks also to enlarge others." (James Legge, 1966, pp. 77) The explanation for "Ren" by Confucius is not satisfied by its "to love all men", because, as a persuasive thought, it should have a reasonable explanation about why people should have the virtue of that. The answer "To subdue oneself and return to Li" gives the reason.

Confucius was born in an era that Zhou Li was collapsed. The princes launched wars between each other in order to get more interests, and the people lived in a miserable and unstable situation. Confucius considered Zhou Li as the best system that ruled the state in the way of "Ren".

"To love all men" shows the basic meaning of "Ren", which stresses individual way of practicing Ren; and "To subdue oneself and return to Li" stresses Ren on the other side that to restrain oneself and follow the Li. The combination of considering for others and restraining oneself shows the two aspects of practicing Ren. Neither can practice Ren sufficiently with itself. The smooth interrelationship is not just established with love, but also with the rules of love.Li is the rule of love to guide the correct way of establishing the relationship. Therefore, consider for others cannot work without Li.

It is started from Confucius that he recognized that "Ren" as a perfect virtue can be practiced and reached by ordinary people. He said: "Is virtue a thing remote? I wish to be virtuous, and lo, virtue is at hand." (James Legge, 1966, pp. 91) "Is the practice of Ren from man itself, or is it from others?" (James Legge, 1966, pp. 157) Confucius thought that the virtue of Ren was indispensable to establish a harmonic society. However, it won't work if Ren can only reached by Kings; therefore he said that the Ren can be owned by anyone, if he wants to practice it.

Confucius used the concept "Xiao Ren", "Jun Zi", and "Sheng Ren" to tell the difference of the virtue among the people. He said: "The Superior man (Jun Zi) thinks of virtue; the small men (Xiao Ren) thinks of comfort. Superior man thinks of sanctions of law, the small man thinks of favors which he may receive." (James Legge, pp. 42)

It is understandable from the words of Confucius that Jun Zhi is the kind of person who can practice Ren, and Xiao Ren is the kind of person who consider for himself. Xun $\mathrm{Zi}$, a famous Confucian after Mencius distinguished Jun $\mathrm{Zi}$ from Xiao Ren with the following criteria: Xiao Ren is the person who can be Jun Zi, but doesn't want to be; and Jun Zi is the person who can be the Xiao Ren but doesn't want to be. Sheng Ren means the sage. Confucius didn't explain what Sheng Ren is. He said: "A sage (Shen Ren) it is not mine to see, could I see a man of real talent and virtue, that would satisfy me.” (James Legge, 1966, pp. 89) Confucius set a Xiao Ren-Jun Zi-Sheng Ren pattern, whoever wants to pursue Ren may realize the goal in the end.

In order to achieve Ren, learning and self-cultivation are the ways to get to it. People should learn in a humble manner. Confucius said: "When I walk along with two others, they may serve me as my teachers. I will select their good qualities and follow them, their bad qualities and avoid them." (James Legge, 1966, pp.87) Zeng Zi said: "I daily examine myself on three points: whether in transacting business for others, I have been not faithful; whether in the intercourse with friends, I may have been not sincere; whether I have not mastered and practiced the instructions of my teacher." (James Legge, 1966, pp. 4)

Confucianism stresses that kings should rule the state with Ren instead of laws, he said: "If the people be led by laws, and if uniformity be sought to be given them by punishments, they will try to avoid punishment, but have no sense of shame" (James Legge, 1966, pp. 13) There is a conversation between Ji Kangzi and Confucius. Ji Kangzi asked: "What do you say about killing the unprincipled for the good of principled?" Confucius replied: "Sir, in carrying on your government, why should you use killing at all? Let you evinced desire be for what is good, and the people will be good. The relation between Jun $\mathrm{Zi}$ and Xiao Ren is like that between the wind and the grass; the grass must bend, when the wind blows across it." (James Legge, 1966, pp. 168) To rule people with virtue of Ren is the perfect way according to Confucianism. The world would be in the great harmony, when both people and rulers have the virtue of Ren.

\section{$1.2 \mathrm{Li}$}

There are many words that can be translated into Li in English. For example, Li can refer to rites, rules of propriety etc. But anyway it means the rules of Confucianism. There is an interactive relationship between Li and Ren. Firstly, Li is made with the principles of Ren. Confucius said: "If a man be without the virtue (Ren) proper to humanity, what has he to do with the rites of propriety (Li)?" (James Legge, 1966, pp. 25) and the second, Ren is the core value of Li, Li 
cannot exist without Ren. As an exterior form of Ren, Li functions as the rule that both regulate people and fosters the virtue of people.

There is a conversation between Confucius and duck Jing of Qi. Duck Jing of Qi asked about government, Confucius replied: "There is government, when the prince is prince, the minister is minister, the father is father, and the son is son." (James Legge, 1966, pp. 165) Confucius thought that the government should follow a fixed Li so that it can build a harmonic society. There should be an order sequence up from son to the prince or king, which is the Li in order.

Duke Ding asked Confucius how a prince should employ his ministers, and how his ministers should serve their prince. Confucius said: "A prince should employ his minister according to Li; ministers should serve their prince with faithfulness." (James Legge, 1966, pp. 33) It is said: "As a sovereign, he rested in benevolence. As a minister, he rested in reverence. As a son, he rested in filial piety. As a father, he rested in kindness." (James Legge, 1966, pp. 318)

Just as Li cannot do without Ren, Ren cannot do without Li, either. Anyone who wants to be Ren has to follow something, because he doesn't know what Ren is yet. Li is the rules created according to Ren, which can be the guidance to be followed and to reach Ren. Therefore, Confucius said: "Look not at what is contrary to propriety; listen not to what is contrary to propriety; speak not what is contrary to propriety; make no movement which is contrary to propriety.” (James Legge, 1966, pp. 156)

Confucianism stresses that the key point of $\mathrm{Li}$ is in the family. If the family, especially the family of king's can follow $\mathrm{Li}$ and be Ren, the state will be in a harmony. "From the loving example of one family, a whole State becomes loving; and from its courtesies the whole State becomes courteous while, from the ambition and perverseness of the One man, the whole State may be led to rebellious disorder;-- such is the nature of the influence. This verifies the saying, 'Affairs may be ruined by a single sentence; a kingdom may be settled by its One man'." (James Legge, 1966, pp. 330) Li sets the order, not only to the ordinary people, but also to the king, the realization of the harmony needs the contribution from all the persons under the order of $\mathrm{Li}$.

\subsection{Dao}

"What Heaven has conferred is called nature; an accordance with this nature is called the path of duty (Dao); the regulation of this path is called instruction.", "The path (Dao) may not be left for an instant. If it could be left, it would not be the path." (James Legge, 1966, pp. 349-350) "While there are no stirrings of pleasure, anger, sorrow, or joy, the mind may be said to be in the state of equilibrium. When those feelings have been stirred, and they act in their due degree, there ensues what may be called the state of harmony. This equilibrium is the great root from which grow all the human actings in the world. And this harmony is the universal path which they all should pursue." (James Legge, 1966, pp. 351) Confucianism call this the Dao of Mean (Doctrine of Mean).

Confucianism defines Dao in two sorts: the Dao of heaven and the Dao of men. The main difference between Dao of heaven and Dao of men is that Dao of heaven do with sincerity itself, while Dao of men do for both itself and others. However, men has to learn Dao, and when he has learnt Dao, he reach the Dao of heaven. But no one had ever achieved that; even Confucius didn't achieve that either. He said: "If men in the morning hear the right way (Dao), he may die in the evening without regret." (James Legge, 1966, pp. 41)

There is a difference between Ren and Dao, too. Ren stresses self-education and pursues Ren for oneself with the way of considering for others. However, the person with Dao, is not who is just the person with Ren, he should practice Ren and help others to be Ren, instead of just considering for others. When Dao of men reaches Dao of heaven, there will be the Great harmony.

Confucianism built a system that comprises of Ren, Li and Dao, which constructed an ideal that the people pursue Ren and further the Dao in the inner while ruling the state with the perfect virtue outside. However, it is worthy of reconsidering this system and see what happens really inside, in order to find the reasons especially when the rule of law meets difficulties.

\section{Rule of Ren and the Lost of Individual}

"In ancient times, men learn with a view to their own improvement. Nowadays men learn with a view to the approbation of others." (James Legge, 1966, pp. 207) Confucius raised an important point that men should learn for themselves, which is the starting point to be Ren. Self-cultivation is the way to reach Ren, and Ren is the embodiment of self-cultivation.

It seems that there is a contradiction when it is said that the meaning of Ren is "for all men", while saying that learning is for oneself. But, there is not a contradiction at all. The men who want to consider for others should improve his virtue first through self-cultivation, because "for others" is the emotion that anyone can have at the specific moment. However, "for others" said by Confucius is not the emotion in short time but the virtue as the belief in heart. For example, a man may practice Ren today, but give it up tomorrow. Ren cannot be genuine in this way. Therefore, Confucius worried about "Leaving virtue without proper cultivation; not thoroughly discussing what is learned; not being able to move 
towards righteousness of which knowledge is gained; and not being able to change what is good." (James Legge, 1966, pp. 79)

Family is a very important concept in Confucianism. Confucius said: "'A youth, when at home, should be filial, and, abroad, respectful to his elders. He should be earnest and truthful. He should overflow in love to all, and cultivate the friendship of the good. When he has time and opportunity after the performance of these things, he should employ them in polite studies." (James Legge, 1966, pp. 5) "The superior man (Jun Zi) bends his attention to what is radical. That being established, all practical courses naturally grow up. Filial piety and fraternal submission! -- are they not the root of all benevolent actions?" Family is the place where parents, brothers and sisters live, and it is also the place where a person is given birth to. When a person wants to be Ren, family should be the first place where he practices Ren. It is incredible to talk about Ren without being Ren to his parents, brothers and sisters.

However, to reconsider the second meaning of Ren, it is clear that the purpose of Ren is to return to Li, or the harmonic order. Confucian thinks "there are few who, being filial and fraternal, are fond of offending against their superiors." (James Legge, 1966, pp. 2)Filial piety and fraternal submission are the Ren of the family, but also they take persons away further from self-consideration. The person will consider for other numbers first in the family, and then consider for others outsider the family too.

Richard Nisbett said that "Chinese social life was interdependent and it was not liberty but harmony that was the watchword- the harmony of humans and nature for the Taoists and the harmony of humans with other humans for the Confucians." "The world was complicated and the events were interrelated, and objects were connected "not as a piece of pie, but as ropes in a net." (James Legge, 1966, pp. 37)

Nisbett sees the basic pattern that Confucianism weaves the world in the "net" with its systematic thoughts. However, Nisbette's picture seems that it is the knots that connect ropes. The interrelationship should be between the individuals according to this explanation. However, there is not the concept of individuals at all in Confucianism, because individual value is buried in the family.

Law as a tool to rule isn't the first choice for Confucianism. Confucius thought that the people ruled by law won't have the sense of shame, because it isn't a civilized way to rule the people but the supplementary of moral. Therefore Confucius stressed the self-cultivation, which restrains oneself and considers for others in order to be a Jun $\mathrm{Zi}$. It is quite different from liberalism, which stresses on individual rights for the purpose of oneself. There are two distinguishing pictures between Confucianism and liberalism. The former stresses the restraining of oneself and practice Ren for the aim of Great Harmony, while the latter stresses the restraining of ruler's power and the aim at the realization of individual rights.

When we talk of the rule of law, we cannot put rights and obligations aside, especially rights. However, rights are something that needs to ask for, or even fight for originally, and they cannot be given by the ruler. Because it will mean that the ruler can give rights according to his own will, and the people don't have the rights to choose. Rights just concerns with the person who owns them, and there is nothing about others. Therefore rights absolutely belong to who owns them. On the contrary, it is significant for Confucianism put others in the first consideration.

It is easy to understand that family is the first rope to restrain the person from challenging the power of the ruler, or fight for rights, because the individual cannot be an independent one from the family, and he has to be filial with submission. Individual value is showed in filial piety, and filial piety and fraternal submission mean that individual should follow the rule of $\mathrm{Li}$ and restrain oneself in the family, which may understand as the first "rope" away from individual rights. Self-restraint is the main characteristic of Confucianism; it keeps one away from gaining, in order to complete the goal of Ren. However, self-restraint also keeps one away from law, because one doesn't consider for himself, which means he values less about his rights. The harmony is of more importance than individual rights when the disputes happen, because the harmony is built with Ren and Li, This leads to the result that people don't have the awareness of individual rights in mind at all.

\section{The Rule of $\mathbf{L i}$}

The motive of Confucianism is to return to $\mathrm{Li}$, which can create the harmonic world. Confucius wrote down the events that princes rebelled against Zhou Dynasty in his famous work "Spring and Autumn", which feared the rebellious princes. Li forms the order, and the order makes the harmony possible. "The Three Cardinal Guides", which set an order that the ruler guides his subject, father guides son, and husband guides wife" constructs the core contents of Li. It draws a clear picture about the relationship between the ruler and subjects; father and son; husband and wife.

There is contradiction between $\mathrm{Li}$ and Ren, according to "The Three Cardinal Guides". It can be explained that father is the authority of son; husband is the authority of wife, and the ruler is the authority of subjects; whereas Ren is about how much the men have the virtue. The more the virtue he has, the closer he nears Ren. Ren is reached by the way of self-cultivation and consideration for others. It is about virtue. However, the titles of ruler, father and husband don't necessarily mean the good virtue or Ren. Why should subjects, son and wife follow them? How if they don't have the 
virtue of Ren while subjects, son and wife are following them? If so, how can Ren be practiced and can the harmony be realized?

Neither Confucius nor Confucians discussed about the questions above. On the contrary, Confucius thought that Li should be obeyed, even though the ruler is bad. Confucius said: "Shao is perfectly beautiful and also perfectly good; Wu is perfectly beautiful but not perfectly good." (James Legge, 1966, pp. 273) Shao was the music of Yu who ruled the people with virtue and the $\mathrm{Li}$ of comity, whereas $\mathrm{Wu}$ is the music of King Wu who overthrown Shang Dynasty. Confucius said that the music of $\mathrm{Wu}$ was not perfectly good, because what King Wu had done was not in accordance with the principle of $\mathrm{Li}$.

Confucius raised three examples to show who people should follow. He said: "The viscount of Wei withdraws from court. The viscount of Qi became a slave of Zou. Bi Gan remonstrated with him and died." "The Yin Dynasty possessed three men of Ren." (James Legge, 1966, pp. 72)

King Zou was a very atrocious man, but Wei Zi, Qi Zi and Bi Gan was very loyal to him and expostulated with King Zou for ruling the state in the proper way. Confucianism stresses on Li, but it doesn't give a resolution of how if the authority doesn't obey Li. Therefore, Li put the obligation and obedience on the shoulder of subjects, son and wife, and didn't give the persuasive reasons for why they should follow it when ruler, father and husband don't follow the principles of Ren.

Dao is the way what Jun Zi should pursue according to Confucianism. Confucius said: "Let the will be set on the path of duty (Dao). Let everything attainment in what is good be firmly grasped. Let perfect virtue (Ren) be accorded with, and let relaxation and enjoyment be found in the polite arts." (James Legge, 1966, pp. 222) Dao was put in the important place in Confucianism. However, just as I mentioned above, Confucianism didn't give a resolution on what if the ruler doesn't have Dao or the ruler rules in a way against Dao. Confucius chose to keep silence under such circumstances. He said: "a superior man (Jun Zi) indeed is Chu Po Yu! When good government prevails in his state, he is to be found in office. When bad government prevails, he can roll his principles up, and keep them in his breast." (Richard E. Nisbett, 2005, pp. 19)

Confucianism stresses that Ren should be pursued through self-cultivation, and to practice Ren should follow Li, which leads to a tendency in thought to avoid conflicts as much as possible. There are two parallel ways for people to be Ren. It is sure that Ren will be realized if people really consider for others and restrain themselves; however, Ren, or the perfect virtue is not based on the precondition that people have individual Rights, with which they can resort to law when their rights are violated, or he may endure the violation of rights if he like. Therefore, self-cultivation is a way to give up the desire to fight or to make efforts to get self-interests actually. Li is another way to pursue Ren, because Ren is the perfect virtue invisible. Li as the guidance plays the role of guiding how to be Ren. Therefore, Li is the exterior form of Ren, while self-cultivation is the inner way of pursuing Ren. Combining the two together is the way of pursuing Ren. To study Li, it is clear that $\mathrm{Li}$ is the rules of obeying instead of the rules of claiming.

The final goal of Confucianism, the Great Harmony, in fact is the matter of Li. It is natural for those who are well self-cultivated will follow $\mathrm{Li}$, and when all the people can follow Li naturally, the Great Harmony will be realized. Harmony is the concept not about right or wrong, but about whether Li is well followed. Therefore, when disputes happen, the key to solve it lies in Li.

\section{The Rule of Man}

Confucius called King Wen, the son of heaven, which means King Wen was legitimated by the authority from heaven. From then on, the Emperors were called the Son of Heaven by Confucius; rulers were given the legitimate authority in the theory without confirming what the heaven is and what standards the Son of Heaven should meet. There is a dilemma here whether the Son of Heaven can reach heaven as Emperor Yao or King Wen did? If he can, what if he is a bad ruler? Would the bad Son of Heaven rule people with justice? Would the heaven exist with justice, while the son of heaven doesn't have the sense of justice?

In fact, Confucianism after Han Dynasty compromised with the government, and named the emperor as the Son of Heaven; in return, the emperor set Confucianism as the authoritative thought in the state. The emperor was educated with Confucianism too. However, whether the emperor would follow Li depends on himself; there is no coercion to be imposed on the emperor, because he is legitimated by heaven instead of the people. Therefore, the people can do nothing but expect that there is the sage-king as Emperor Yao or King Wen. The ruler or the emperor is in fact the absolute authority on the earth, and the subjects must follow him.

The five relationships such as the relationship between the rule and subjects; father and son; husband and wife; elder brother and younger brother; friends created by Confucianism stressed $\mathrm{Li}$ in them. However, there is clearly the authority sequence from the top to the bottom. Each pair of relations has an authority legitimated by $\mathrm{Li}$. Rule of $\mathrm{Li}$, or rule with the principles of Ren, means rule of the man with the perfect virtue. But the ideology of Confucianism can just be the utopia, because Confucianism is so weak on the restraint of the ruler. 
On the one hand, Confucianism constructs a stable foundation of the order for the ruler, which weakens the challenges from the subjects; on the other hand, it places itself under the order that it has to follow Li. Therefore, Confucianism is not the philosophy or the thought set from the sight over the human world, because it doesn't cover all humans with its Li. The ruler is the exception. Neither is Confucianism a theory that the starting point is for the happiness of the individual, even though it stresses on ruling with perfect virtue.

Returning to the harmony, in other words, the perfect order is the starting point of Confucianism. The whole thought system is constructed with the steps on how to rebuild the harmony. Confucianism indeed contributed a great deal to the stability of the order, while it fostered the thought that following $\mathrm{Li}$ is a natural obligation. Thus, the rule of man doesn't seem an improper way.

Under the rule of man, law is just as the sword in man's hand, whereas, under the rule of law, law is the sword suspending over man's head. Man is restrained under the rule of law, even though man can take advantages of legislature and make bad laws. The man would be punished by laws, too, when he violates the laws. This is the fundamental difference between the rule of law and the rule of man.

Confucianism constructed an hierarchical system that guarantees the ruler has the absolute power in hand with its theoretical support; in which the rule of law just like an alien, far away and incomprehensible. Law is just the tool for the rule of Li according to Confucianism. Law can do nothing when everything is in smoothly proceeding with Li. However, $\mathrm{Li}$ is the order for the rule of man; therefore, law becomes the guard of man, instead of the restraint of man.

Just as the importance of natural law to the rule of law, Confucianism functions as the same role to the rule of man. The difference is that the former stressed that the natural law and its justice is above all people on the earth and should be obeyed by all people. There are plenty of reasons for restraining the ruler when he abuses his power according to natural law. Natural law permits people to pursuit equality and liberty and the rule of law, furthermore the individual rights. However, Confucianism works in an opposite direction in the consideration of return to Li, the perfect order that Zhou Dynasty had had, and it constructs a moral system in order to theoretically set up a stable order. Therefore, Confucianism is not the theory starting its point from individual, but from the purpose of setting the order in society. Its Ren, $\mathrm{Li}$ and Dao, all follow the motive of rebuilding of the perfect $\mathrm{Li}$, individual is just one of the "knot" on the net; and how to make the knot suitable for the net is in the first consideration. Ren, Li and Dao all are the very efficient means to make the suitable knots in society.

Indeed, Confucianism didn't say that it is for the rule of man. However its theoretical system persuade people restrained oneself and for others in order to achieve Ren on the one hand, and then restrain Ren with Li that construct a hierarchical system on the other hand. Therefore, Confucianism sowed the seeds for the rule of man in people's mind, which formed the foundation of Chinese thoughts. Also, individual was valued little in Confucianism. It would be confused when one fight for his own rights, because there is nothing about individual rights in Confucianism. Individual should only do "self-cultivation", "self-restraint" etc. and serve or help others in following Li. The examples in the Chinese tradition are those who devoted life to the ruler or the state instead of fighting for individual rights. Individual rights are just shame in Confucianism; which is, on the contrary, the foundation of the rule of law.

Under the rule of law, justice casts its care to individuals with restraining the power of ruler. This embodies the humanness specifically. Individual is equal when they are given to birth. Therefore, there should not be pre-authorized person who can be above others with the absolute power. Rule of law is the way that individual can be treated equally as much as possible. The protection of individual rights is the highest goal.

Still, when we see deeply the Confucianism and its blueprint of $\mathrm{Li}$, isn't it a feeling of the building under the construction proceeding with brick one by one? While Westerners question why individuals should be ruled by someone that they don't know, Chinese think how to remember the code of Confucianism and be a Jun $\mathrm{Zi}$, or how to achieve the dream in the way towards to the official by passing the examination designed with Confucianism. Therefore, what Chinese thought is about how to be a nice part of the pre-designed building, whereas westerners thought why should the building designed in that way.

Ren is the essence of Confucianism; however, when it defines the rule of Li, the submission from lower to the upper becomes the part of Li. Unfortunately, Ren can be the principle of $\mathrm{Li}$, but it cannot be the formal rule that can be carried out. However, the Li of submission can be carried out; therefore, individual must follow the ruler. Ren cannot be carried out in form; therefore, the ruler can be either Ren or not. The democracy under this condition would just be the rhetoric without real value.

Formal Legality and Independent Judiciary become the luxuries under the rule of man. The Generality, Equality and Certainty won't be guaranteed when there is a ruler with unlimited authority. Law is but a tool in his hand, and he can use it to do anything. Confucians expected there may be a sage-king born someday. However, in fact, in Chinese history, there were not too many sage-king except Emperor Yao, Sun, Yu and King Wen; instead, there were many tyrants and mediocre rulers. There weren't an equal Ren from the ruler, but only the favor or grace from the ruler to those who 
show loyalty. The uncertainty instead of the certainty is the characteristic of the rule of man. Formal Legality and Independent Judiciary don't have a real foundation under such a condition.

We can find that there is not anything can be found in Confucianism relating to the rule of law. Law is just the second consideration of it, which is a tool for the rule of man. The consideration in this way in fact set a wall in between the rule of man and the rule of law. The people don't have the knowledge about law, and the law was not considered as an independent part to be developed. It is quite clear to westerners to go to the judge when there is a conflict. However, there is not a concept of Judge in Chinese mind. Chinese regards the governor as the judge. There are not clear concepts to tell the governor from the judge, they seem the same. It is taken for granted that the government is the place for lawsuits, and the governor is the judge. With the explanation of Confucianism that the emperor is the Son of Heaven, that governor is the representative of the Son of Heaven. Therefore the judge by the governor has the legalization. Guan, the governor, is called the "Fu Mu Guan", which means the parents. On the one hand, Chinese see governor as the parents and subjected to him; on the other hand, Chinese leave their fate to the governor. This is not because they believe the governor would help them; it is because the procedure to the governor is the last chance Chinese to see the justice. The story of Bao Gong, a governor in Song Dynasty who sentenced his niece to death for justice, is passed from generation to generation. Chinese hopes that all the governors treat people like Bao Gong.

There is not a resolution in Confucianism on what if the emperor or the governor doesn't act as he should be. Li as the rules is a very efficient tool of ruling the people, and there is law behind it when $\mathrm{Li}$ in the law is violated. However, there isn't a law behind the $\mathrm{Li}$ of the emperor, thus, when the emperor violate $\mathrm{Li}$, there is no more than the expostulation from the ministers, those who may risk the punishment from the emperor. The action challenging the authority from the emperor is not in accordance with Li, let alone the rebellions. The story about the national hero, Yue Fei, is so popular that Chinese admire him; whereas the ex-minister, Qin Hui who did the persecution, to a death penalty of Yue Fei have been cursing by Chinese. However, the emperor who sanctioned penalty isn't blamed too much. Chinese admire Yue Fei, because he was so loyal to the emperor that he would rather be sentenced to death than betray the emperor. "Loyalty" is the reason that why Chinese admire him; however, there was not an answer on how to avoid that case. Confucianism set the principles of Ren, to consider for others, to be loyal to the emperor, which leads to an inclination in Chinese personality that they seldom asked "why". The self- cultivation is the road to Ren through the consideration for all the others in society. However, the contradiction is that how if the others don't consider for you, how if the governors don't consider for you, and how if the emperor doesn't consider for you. Since people have the inclination that consider for others as the good virtue, the word "individual interests" is equal to egoism, a taboo in Confucianism. However the basic concept of the rule of law is "rights", the rights handed in individual's hand. To fight for the right given by law has nothing to do with the shame and the badness in virtue in westerner's eyes.

The ideology of Confucianism just likes a dream, far and charming. It is worthy of sacrificing individual interests for the Great Harmony in the eyes of those who pursue Dao. The steps of Self-cultivation, harmonizing the family, contributing to the country and harmonize the world shows a brilliant road to the people. However, Ren is limited by Li. When Ren is explained to "for others", "for the great harmony", there is a precondition that, people must follow Li. In the family, son should be loyal to father, and wife follow husband, younger brother follow elder brother. But son should be filial to his father even if his father doesn't consider for others, or even does an illegal thing. In this sense Ren is subject to Li.

Therefore the Great Harmony cannot be the harmony that people live with an equal status and rights. Also, it is Li that set the authority in various aspects. There is not a guarantee that the authority will definitely consider for others, let alone "love my parent and love other parents". And further, the ideology of Great Harmony was set based on the self-realized Ren.

The sequence for the ideology is just upset down in between Confucianism and individualism. Instead of pursuing the ideology with sacrificing individual interests, westerner pursues ideology based on the realization of individual interests. Taking the individual rights in hand first, and then pursues more rights and interests. The realization of individual rights requires the restraint of the power from the above and the rights from the same level. The more restraint of the power from the above, the more rights the people can have.

\section{Conclusion}

Confucianism created a system that people pursue perfect virtue in order to realize the great harmony society. However, its values led to the trend to be away from the rule of law. In addition, Confucianism loses its consistency in thought when it cannot restrain the authority effectively with $\mathrm{Li}$, which lead to the regret that the humanness it stressed on may be in danger. Westerners criticize China on its human rights, but ignore tradition that rooted in Chinese blood. Nowadays, the rule of law has been written in Chinese constitution, but Chinese still think in Confucianism way subconsciously, law still is not a favorable way to solve the disputes. Chinese is trying to combine Confucianism value with the rule of law, in order to construct a harmonic society, the study on Confucius thinking way will contribute a lot on the way to the rule of law. 


\section{References}

James Legge. (1966). The Four Books, New York: Paragon Book Reprint, pp. 171.

James Legge. (1966). The Four Books, New York: Paragon Book Reprint, pp. 155. James Legge. (1966). The Four Books, New York: Paragon Book Reprint, pp. 77. James Legge. (1966). The Four Books, New York: Paragon Book Reprint, pp. 91. James Legge. (1966). The Four Books, New York: Paragon Book Reprint, pp. 157. James Legge. The Four Books, New York: Paragon Book Reprint, pp. 42. James Legge. (1966). The Four Books, New York: Paragon Book Reprint, pp. 89. James Legge. (1966). The Four Books, New York: Paragon Book Reprint, pp. 87. James Legge. (1966). The Four Books, New York: Paragon Book Reprint, pp. 4. James Legge. (1966). The Four Books, New York: Paragon Book Reprint, pp. 13. James Legge. (1966). The Four Books, New York: Paragon Book Reprint, pp. 168. James Legge. (1966). The Four Books, New York: Paragon Book Reprint, pp. 165. James Legge. (1966). The Four Books, New York: Paragon Book Reprint, pp. 33. James Legge. (1966). The Four Books, New York: Paragon Book Reprint, pp. 318. James Legge. (1966). The Four Books, New York: Paragon Book Reprint, pp. 156. James Legge. (1966). The Four Books, New York: Paragon Book Reprint, pp. 330. James Legge. (1966). The Four Books, New York: Paragon Book Reprint, pp. 349-350. James Legge. (1966). The Four Books, New York: Paragon Book Reprint, pp. 351. James Legge. (1966). The Four Books, New York: Paragon Book Reprint, pp. 41. James Legge. (1966). The Four Books, New York: Paragon Book Reprint, pp. 207. James Legge. (1966). The Four Books, New York: Paragon Book Reprint, pp. 79. James Legge. (1966). The Four Books, New York: Paragon Book Reprint, pp. 5. James Legge. (1966). The Four Books, New York: Paragon Book Reprint, pp. 2. James Legge. (1966). The Four Books, New York: Paragon Book Reprint, pp. 37. James Legge. (1966). The Four Books, New York: Paragon Book Reprint, pp. 273. James Legge. (1966). The Four Books, New York: Paragon Book Reprint, pp. 72. James Legge. (1966). The Four Books, New York: Paragon Book Reprint, pp. 222.

Richard E. Nisbett. (2005). The Geography of Thought: how Asians and Westerners think differently-- and why, London: Nicholas Brealey, pp. 19. 